\title{
Ethnoecological knowledge of ticks and treatment of tick-borne diseases among Maasai people in Northern Tanzania
}

\author{
John Kioko ${ }^{1}$, Julia Baker ${ }^{2}$, Avery Shannon ${ }^{3}$ and Christian Kiffner ${ }^{1}$ \\ 1. Center For Wildlife Management Studies, School for Field Studies, P.O. Box 304, Karatu, Tanzania; 2. Biochemistry \\ Program, Vassar College, Poughkeepsie, New York, USA; 3. Department of Biology, University of \\ Richmond, Virginia, USA. \\ Corresponding author: John Kioko,e-mail: jkioko@fieldstudies.org, kiokostar@yahoo.com, JB: jubaker@vassar.edu, \\ AS: ashannon127@gmail.com, CK: ckiffner@fieldstudies.org \\ Received: 28-02-2015, Revised: 09-05-2015, Accepted: 17-05-2015, Published Online: 20-06-2015
}

doi: 10.14202/vetworld.2015.755-762 How to cite this article: Kioko J, Baker J, Shannon A, Kiffner C (2015) Ethnoecological knowledge of ticks and treatment of tick-borne diseases among Maasai people in Northern Tanzania, Veterinary World 8(6):755-762.

\begin{abstract}
Aim: The aim of this study was to understand traditional knowledge of tick ecology and remedies for tick-borne diseases (TBDs) among the Maasai people in northern Tanzania.
\end{abstract}

Materials and Methods: Semi-structured interviews were conducted among specific groups likely to be knowledgeable about tick ecology and TBDs in livestock among the Maasai people.

Results: A total of 25 plant species belonging to 18 families were used to treat 8 different TBDs of livestock. Most of the plant species used were of Fabaceae and Burseraceae families. Aloe volkensii, Cissus grandifolia, and Terminalia brownii were the most commonly used plant species. The major plant growth form used was trees, while stems and bark were the main plant parts used. Most treatments were taken orally.

Conclusion: Maasai people have substantial knowledge on tick ecology exemplified by their ability to differentiate between different tick species and the range of remedies for each of the TBDs. Because traditional ethnoveterinary remedies are frequently utilized, their effectiveness should be further investigated.

Keywords: ethnoveterinary medicine, Maasai, Tanzania, tick-borne diseases, tick ecology.

\section{Introduction}

The Maasai traditionally live a pastoral lifestyle in parts of East Africa [1] and are known to have a strong culture with customs and norms manifested in their knowledge of traditional system of livestock keeping. In East Africa, tick infection and tick-borne diseases (TBDs) are prevalent and a severe constraint to livestock keepers [2]. In some pastoral areas of Tanzania, calf mortality of cattle reaches $40-80 \%$ due to East Coast Fever (ECF), amounting to yearly losses of about USD 43 million [3]. In the Ngorongoro area in northern Tanzania, TBD infection rate is $85.6 \%$ [4]. While Maasai people experience continuous and seasonal outbreaks of TBDs [5], their knowledge on tick ecology and epidemiology is not well documented [4].

Traditional knowledge is critical in disease prevention, control, and treatment, and may enhance cost-effective management of TBDs in livestock [6]. Past studies suggest that the treatment seeking behavior in rural areas is closely related to their cultural knowledge, with people often seeking the locally available options first [7]. Furthermore, there is continuing loss of traditional knowledge among the Maasai people as they adopt new lifestyles [5]. This is unfortunate because traditional knowledge on TBDs

Copyright: The authors. This article is an open access article licensed under the terms of the Creative Commons Attributin License (http:// creative commons.org/licenses/by/2.0) which permits unrestricted use, distribution and reproduction in any medium, provided the work is properly cited. may help enrich modern pharmacology [8]. The objective of this study was to examine and document the ethno-ecological knowledge of ticks and TBDs among the Maasai people of Northern Tanzania. The specific objectives were to common tick species and associated TBDs in livestock, identify plants and plant parts used to prepare remedies for TBDs, and document how the remedies are prepared and administered among the Maasai of Northern Tanzania.

\section{Materials and Methods}

\section{Ethical approval}

In order to protect the rights and welfare of the interviewees, guidelines based on the School For Studies Institutional Review Board (IRB) - IRB-TZ-01-13 were followed.

\section{Study area}

The study was undertaken in Monduli district within the villages of Esilalei, Losirwa, and Eselela, within Arusha Region in Northern Tanzania. The area is a semi-arid savannah, with an average annual rainfall of $650 \mathrm{~mm}$ [9]. We worked in pastoral areas bordering Lake Manyara National Park and Manyara Ranch, that are commonly used by dispersing and migrating wildlife [10]. The ecosystem is rich in wildlife diversity with about 350 birds, 290 reptiles, and 40 amphibian species [11] and a host of large mammal species. The area is mainly used by the Maasai people for livestock grazing [11-13]. 


\section{Sampling procedure}

Interviewees were selected based on a purposive sampling procedure [14]. Twenty three livestock keepers likely to be knowledgeable in tick ecology, and TBDs were identified by asking elders in each village. These included 15 men, 5 women, and 3 individuals known to specialize in traditional veterinary medicine. A livestock veterinarian of the Maasai tribe was consulted so as to corroborate some of the information, e.g., the English names for specific TBDs and names of tick species. Among these groups, semi-structured [15] and informal interviews [16], were undertaken within a period of 10 days.

Authors 2 and 3 conducted the interviews assisted by a translator well versed in English and Maasai ( $m a a$ ) language. The interviewees were shown pictures of ticks [17] and requested to give the maa tick species name and associated disease known to be transmitted by that tick species. Other information collected during the interview included: the preferred habitat of each tick species, tick species-specific attachment sites, seasonal occurrence, and the main host species affected. In addition, we asked about details on possible treatment methods. We asked what kind of plant and other parts/products were used, how the medication was prepared and applied, and how available and effective the treatments were. Plant walks in the villages were undertaken for 2 days to collect and identify the plants used for TBD treatment. A Likert scale rating [18], where $(1=$ common $2=$ relatively common [required searching in the village] $3=$ rare [rare in the area and has to be sought far]) was used to characterize the availability of each plant. The perceived tick remedy effectiveness was classified as: $1=$ rarely effective, $2=$ moderately effective, $3=$ very effective.

\section{Statistical analysis}

A checklist of plant species used for TBD remedies was generated and taxonomic classification undertaken [19]. A Chi-square goodness of fit test was used to determine differences in perceived level of effectiveness and species availability for treatment of TBDs.

\section{Results}

Traditional knowledge on tick ecology among the Maasai

A total of 4 common maa names were used to describe six species of ticks found in the area. Ticks were said to prefer shaded areas, grass tops, and bark crevices and were said to be most abundant in the dry season. The local tick control methods mentioned included pasture burning (5\%), hand picking (15\%), topical application of kerosene (70\%), and cow dung to remove ticks $(10 \%)$. However, pasture burning $(5 \%)$ was said to be practiced in limited cases as it reduces the available grazing land (Table-1). All interviewees relied on the use of acaricides for tick control.

Eight different diseases associated with ticks were noted. Their maa names were given as Anaplasmosis (Oltikana oirobi), ECF (Oltikana oirowa), sweating sickness (Oltikana Looholo), heartwater (Ormilo), corridor disease (Engeeya Osero), red water (Olodokulak), lumpy skin disease (LSD) (Ormoko), and Brucellosis (Orkibiroto). When asked about the vector for each of the TBDs, Anaplasmosis (62\%), ECF (56\%), Sweating Sickness (50\%), and heartwater $(22 \%)$ were highly associated with ticks. Corridor disease (18\%), Babesiosis (red water) (9\%), LSD (5\%), and Brucellosis (5\%) were rarely associated with ticks (Table-2).

When asked about the specific tick species that transmitted the pathogens causing each TBD disease, Brucellosis (100\%), LSD (100\%), and anaplasmosis $(86 \%)$ were highly associated with the known tick vector (Table-2). None of the respondents knew the tick species that transmitted the pathogens causing corridor and red water diseases. Other agents believed to cause TBDs included new grass, insects, birds such as oxpeckers, dirty water, and other diseases.

\section{Important medicinal plants for treatment of TBD}

The interviewees reported 25 plant species, from 18 families and 21 genera to be used to treat the 8 different TBDs. The most common plant families used were Fabaceae (25\%) and Burseraceae (8\%). Most of the treatments $(60 \%)$ were from trees, compared to shrubs $(28 \%)$ and herbs $(12 \%)$. Stems $(33 \%)$ and bark $(29 \%)$ were the most used plant parts when compared to leaves $(16 \%)$ and roots $(14 \%)$, fruits $(14 \%)$, sap $(2 \%)$, and branches $(2 \%)$. Most of the plants were said to be readily available locally or in the nearby foothills, however, some of the herbs were only available during the rainy season. The most important plant reported to be used was Aloe volkensii, and was used to treat 6 of the 8 TBDs (Table-3). The next most important plants were Cissus grandifolia and

Table-1: Ecological knowledge of ticks among the Maasai in Northern Tanzania.

\begin{tabular}{|c|c|c|c|c|c|c|}
\hline Tick species & $\begin{array}{l}\text { English tick } \\
\text { name }\end{array}$ & $\begin{array}{l}\text { Local tick } \\
\text { name }\end{array}$ & $\begin{array}{l}\text { Preferred } \\
\text { habitat }\end{array}$ & $\begin{array}{l}\text { Observed } \\
\text { attachment site }\end{array}$ & $\begin{array}{l}\text { Main } \\
\text { season }\end{array}$ & $\begin{array}{l}\text { Animal } \\
\text { affected }\end{array}$ \\
\hline $\begin{array}{l}\text { Amblyomma variegatum; } \\
\text { Hyalomma truncatum }\end{array}$ & $\begin{array}{l}\text { Bont tick; bont- } \\
\text { legged tick }\end{array}$ & Armaheripus & $\begin{array}{l}\text { Under trees, } \\
\text { under grass }\end{array}$ & $\begin{array}{l}\text { Anus, groin, } \\
\text { dewlap, udders }\end{array}$ & $\begin{array}{l}\text { Dry } \\
\text { season }\end{array}$ & $\begin{array}{l}\text { Cattle, } \\
\text { goat, sheep }\end{array}$ \\
\hline Rhipicephalus decoloratus & Blue tick & $\begin{array}{l}\text { Endenuri/ } \\
\text { Armaherikima }\end{array}$ & $\begin{array}{l}\text { Top of tall grass, } \\
\text { top of short grass }\end{array}$ & $\begin{array}{l}\text { Anus, ears, eyes } \\
\text { (softer skin areas) }\end{array}$ & $\begin{array}{l}\text { Dry } \\
\text { season }\end{array}$ & Cattle, goat \\
\hline $\begin{array}{l}\text { Rhipicephalus appendiculatus; } \\
\text { Rhipicephalus spp.; } \\
\text { Rhipicephalus evertsi evertsi }\end{array}$ & $\begin{array}{l}\text { Brown tick; red } \\
\text { tick; red-legged } \\
\text { tick }\end{array}$ & Armaheriodo & $\begin{array}{l}\text { Top of tall grass, } \\
\text { bark of trees }\end{array}$ & $\begin{array}{l}\text { Anus, base of tail, } \\
\text { dewlap }\end{array}$ & $\begin{array}{l}\text { Dry } \\
\text { season }\end{array}$ & $\begin{array}{l}\text { Cattle, } \\
\text { goat, sheep }\end{array}$ \\
\hline
\end{tabular}


Terminalia brownii, which were used to treat 4 of the 8 TBDs investigated. Mode of remedy preparation, form of use, dosage,
and effectiveness

Fifty-nine different treatments for TBDs were mentioned. There were 8 treatments for Anaplasmosis, 5 for Brucellosis, 6 for corridor disease, 9 for ECF, 5 for heartwater, 14 for LSD, 8 for red water, and 4 for sweating sickness (Tables-3 and 4). The majority of treatments were prepared in the form of a solution $(64 \%)$, and topical pastes $(12 \%)$, topical ointments $(10 \%)$, pounds $(10 \%)$, and smoke inhalation $(5 \%)$. Most medicines were administered orally (68\%), topically $24 \%$ or through injection into the skin or nasal cavity ( $8 \%$ ) (Figure-1). In most cases, the treatments were said to be mostly (59.4\%) moderately effective, compared to $17.9 \%$ effective and $22.7 \%$ very effective $\left(\chi^{2}=30, d f=2, \mathrm{p}<0.001\right)$. The dominant animal products used were sheep fat, cattle dung, and cattle ghee. Termite soil, engine oil, salt, and sugar were also used (Table-3). A hot iron was commonly used to burn lesions from LSDs.

\section{Discussion}

\section{Traditional knowledge on tick ecology among the} Maasai

Of the 60 different tick species found in Tanzania, only 4 of them are known vectors for TBDs among Maasai livestock [4,20]. In this study, 6 different tick species were identified and had three maa names. The tick naming is based on the tick's coloration. The brown, red, and red-legged ticks are referred to as Armaheriodo, the bont, and bont-legged ticks are both striped and are called Armaheripus. Similarly, the blue tick is referred to as Endenuri or Armaherikima because of its bluish gray coloration. The blue tick (Boophilus decoloratus) and the brown/red tick (Rhipicephalus appendiculatus and Rhipicephalus spp.), however, are sometimes confused [21]. The red-legged tick, Rhipicephalus evertsi evertsi, was said not to transmit any of the diseases although research suggests its is a vector for ECF [22]. Ticks were said to be more abundant in the dry season. Tick activity increases during the dry season and lulls in the wet months [22]. In addition, increase in TBD instances in the dry season could be due to compromised host immunity as food resources are limited and livestock condition is poor during this time [23]. Furthermore, during the dry season, when water and food are scarce, livestock usually travel further [24], and hence may be exposed more to ticks. Shade is essential in the heat of the dry season, which puts livestock at risk of contracting bont or bont-legged ticks that dwell in the shade or brown ticks that prefer to hide on the bark of trees [22,24]. Feeding site attachment of ticks on livestock could be related to mouth morphology. Both bont tick species have long mouthparts and prefer hairless, tougher skin areas, whereas the blue tick and brown ticks have short to medium mouthparts and attach to softer body parts [22]. However, niche segregation of East African ticks is not fully understood [25].

\section{Knowledge on TBD and tick control}

The traditional tick control methods included burning of old/long grass to kill ticks, applying fresh manure to attachment sites in order to suffocate ticks, hand picking of the ticks and burning them. Kerosene/

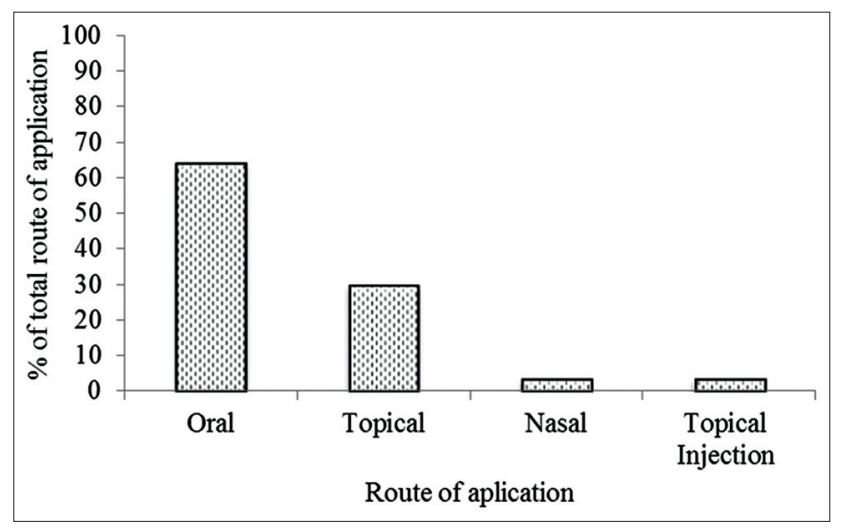

Figure-1: Route of administration for traditional tick-borne disease treatments by Maasai in Northern Tanzania.

Table-2: Perceived causes and tick associations with TBDs among Maasai in Northern.

\begin{tabular}{|c|c|c|c|c|}
\hline Disease & $\begin{array}{l}\text { Tick vector } \\
\text { species (17) }\end{array}$ & $\begin{array}{c}\text { Disease } \\
\text { association (\%) } \\
\text { with ticks by } \\
\text { respondents }\end{array}$ & $\begin{array}{l}\text { Disease association } \\
\text { (\%) with the known } \\
\text { vector tick species } \\
\text { by respondents }\end{array}$ & Other reported causes of TBD \\
\hline Anaplasmosis & Blue tick & 62 & 86 & New grass, grass around rivers \\
\hline Brucellosis & $\begin{array}{l}\text { Blue tick, brown } \\
\text { ear tick, bont tick }\end{array}$ & 5 & 100 & $\begin{array}{l}\text { Other diseases (anaplasmosis, ECF, } \\
\text { bovine pneumonia), starvation }\end{array}$ \\
\hline $\begin{array}{l}\text { Corridor } \\
\text { disease }\end{array}$ & Brown ear tick & 18 & 0 & $\begin{array}{l}\text { Wild animals, tsetse flies, grasses of } \\
\text { deep forest }\end{array}$ \\
\hline ECF & Brown ear tick & 56 & 40 & Green pastures, new grass \\
\hline Heartwater & Bont tick & 22 & 40 & Insect in brain, wild animals, sunlight \\
\hline $\begin{array}{l}\text { Lumpy skin } \\
\text { disease }\end{array}$ & $\begin{array}{l}\text { Blue tick, brown } \\
\text { ear tick, bont tick }\end{array}$ & 5 & 100 & $\begin{array}{l}\text { Red-billed oxpecker, wild animals, } \\
\text { the bush }\end{array}$ \\
\hline Red water & Blue tick & 9 & 0 & $\begin{array}{l}\text { Dirty water, tsetse flies, olopito } \\
\text { grass, other livestock }\end{array}$ \\
\hline $\begin{array}{l}\text { Sweating } \\
\text { sickness }\end{array}$ & Bont-legged tick & 50 & 33 & \\
\hline
\end{tabular}

$\mathrm{ECF}=$ East Coast Fever, $\mathrm{TBD}=$ Tick borne diseases 
Table-3: TBD and associated plant species used for treatment by Maasai in Maasai in Northern Tanzania.

\begin{tabular}{|c|c|c|c|}
\hline Disease & $\begin{array}{l}\text { Plant scientific } \\
\text { name }\end{array}$ & $\begin{array}{l}\text { Plant maa } \\
\text { name }\end{array}$ & Parts used, preparation, dosage, and effectiveness \\
\hline \multirow[t]{8}{*}{ Anaplasmosis } & Cissus grandifolia & Endijai & $\begin{array}{l}\text { Feed the animal a handful of pounded plant, } 1 \text { time }(x) / \text { day, } \\
\text { for } 2-3 \text { days }\end{array}$ \\
\hline & Cissus grandifolia & Endijai & Feed the animal a handful of pounded plant for 1 time $(x) /$ day \\
\hline & Cissus grandifolia & Endijai & $\begin{array}{l}\text { Chop stalk and boil, cool, and feed to animal, } 3 \mathrm{~L}, 1 \times / \text { day for } \\
3 \text { days }\end{array}$ \\
\hline & Cissus grandifolia & Endijai & $\begin{array}{l}\text { Mix plant stalk pound and soda ash, feed small handful to } \\
\text { animal } 1 \times / \text { day for } 5 \text { days, rarely effective }\end{array}$ \\
\hline & Argemone mexicana & Olemoloko & $\begin{array}{l}\text { Pound stem, mix in soda ash with a little of water, feed to cow } \\
0.25 \mathrm{~kg} / 1 \times \text { day for } 3 \text { days, very effective }\end{array}$ \\
\hline & Aloe vokensii & Osukuroi & $\begin{array}{l}\text { Boil leaves and cool, give solution to animal, } 1-4 \mathrm{~L} 1 \times / \text { day for } \\
2-5 \text { days, moderately effective }\end{array}$ \\
\hline & Aloe vokensii & Osukuroi & $\begin{array}{l}\text { Chop leaves and boil, add soda ash, cool, and feed solution to } \\
\text { animal, every effective }\end{array}$ \\
\hline & Commiphora spp. & oldemwai & $\begin{array}{l}\text { Squeeze out sap from stem and apply topically on the ticks, } \\
\text { very effective at removing tick }\end{array}$ \\
\hline \multirow[t]{4}{*}{ Brucellosis } & Ficus sycomorous & Orng'aboli & $\begin{array}{l}\text { Boil bark and let the mix stay for } 2 \text { days, then feed the } \\
\text { solution to the animal } 1 \mathrm{~L} / \text { day }\end{array}$ \\
\hline & Adansonia digitata & Olmasera & $\begin{array}{l}\text { Boil bark and give solution to cattle, } 350 \mathrm{~mL} \text {, once, very } \\
\text { effective }\end{array}$ \\
\hline & Acacia drepanolobium & Eluai & $\begin{array}{l}\text { Boil or soak bark, feed solution to animal, } 1 \mathrm{~L} \text { a day for } \\
2-4 \text { days, very effective }\end{array}$ \\
\hline & $\begin{array}{l}\text { Adansonia digitata and } \\
\text { Acacia nubica }\end{array}$ & $\begin{array}{l}\text { Olmasera and } \\
\text { Oldepe }\end{array}$ & $\begin{array}{l}\text { Boil together bark of both trees, give solution to animal } \\
1 \mathrm{~L} 1 \times \text { day for } 3 \text { days, very effective }\end{array}$ \\
\hline \multirow[t]{5}{*}{$\begin{array}{l}\text { Corridor } \\
\text { disease }\end{array}$} & Cordia sinensis & Edorko & $\begin{array}{l}\text { Chop and boil roots, give solution to animal, } 2 \times \text { daily for } \\
3 \text { days, very effective }\end{array}$ \\
\hline & Terminalia brownii & Orbukoi & Boil/soak bark, give solution to animal, rarely effective \\
\hline & Lannea schweinfurthii & Orpadwa & $\begin{array}{l}\text { Smash roots and collect the juice, feed to animal, } 1 \times \text { day for } \\
3 \text { days, moderately effective }\end{array}$ \\
\hline & Aloe vokensii & Osukuroi & $\begin{array}{l}\text { Boil leaves, give solution to animal } 1 \times \text { day for } 2-3 \text { days, } \\
\text { volume based on body size, moderately effective }\end{array}$ \\
\hline & Aloe vokensii & Osukuroi & $\begin{array}{l}\text { Chop leaves and boil, add soda ash, cool, feed solution to } \\
\text { animal, } 1 \mathrm{~L} 1 \times \text { day for several days, rarely effective }\end{array}$ \\
\hline \multirow[t]{9}{*}{$\mathrm{ECF}$} & Dicrostachys cinerea & Endendundulu & $\begin{array}{l}\text { Boil roots and add soda ash, inject solution up nose } 2 \times \text { day for } \\
4 \text { days, very effective }\end{array}$ \\
\hline & Aloe vokensii & Osukuroi & $\begin{array}{l}\text { Chop leaves and boil, add soda ash, cool, feed solution to } \\
\text { animal, } 1 \times \text { day for several days, rarely effective }\end{array}$ \\
\hline & Aloe vokensii & Osukuroi & $\begin{array}{l}\text { Boil leaves, give animal } 2 \mathrm{~L} \text { of solution } 1 \times \text { day until recovered, } \\
\text { moderately effective }\end{array}$ \\
\hline & Cissus grandifolia & Endijai & $\begin{array}{l}\text { Boil and give solution to animal, take hot iron and burn } \\
\text { swollen glands, } 1-2 \mathrm{~L} 1 \times \text { day until recovered, rarely effective }\end{array}$ \\
\hline & $\begin{array}{l}\text { Acacia mellifera; } \\
\text { Dalbergia melanoxylon }\end{array}$ & Oiti; Oltiasika & $\begin{array}{l}\text { Boil bark from tree and feed solution to animal, } 2 \text { L } 2 \times \text { day for } \\
4 \text { days, moderately effective }\end{array}$ \\
\hline & Kigelia africana & Aldarapoi & $\begin{array}{l}\text { Take sausage fruit, cut up, boil, give solution to animal, } \\
1.5 \mathrm{~L} 1 \times \text { day for } 4 \text { days, very effective }\end{array}$ \\
\hline & $\begin{array}{l}\text { Aloe vokensii; Cissus } \\
\text { grandifolia }\end{array}$ & $\begin{array}{l}\text { Osukuroi; } \\
\text { Endijai }\end{array}$ & $\begin{array}{l}\text { Boil leaves and stalk together and let cool, feed solution to } \\
\text { animal } 1 \mathrm{~L} 2 \times \text { day for } 3-4 \text { days, moderately effective }\end{array}$ \\
\hline & Terminalia brownii & Orbukoi & $\begin{array}{l}\text { Orbukoi bark boiled/soaked in water and fed to animals, } \\
350 \mathrm{~mL}, 2 \times \text { day, until calf recovers, moderately effective }\end{array}$ \\
\hline & Cissus grandifolia & Endijai & $\begin{array}{l}\text { Mix alkaline with plant stalk and feed animal a small handful } \\
\text { of the soda ash/plant mash, rarely effective }\end{array}$ \\
\hline \multirow[t]{10}{*}{ Heart water } & Cissus grandifolia & Endijai & $\begin{array}{l}\text { Chop up and boil, give } 1 \mathrm{~L} \text { of solution } 1 \times \text { day, every other day, } \\
\text { for } 3 \text { days, rarely effective }\end{array}$ \\
\hline & $\begin{array}{l}\text { Albizia gummifera; } \\
\text { Cissus grandifolia }\end{array}$ & $\begin{array}{l}\text { Ormokutan; } \\
\text { Endijai }\end{array}$ & $\begin{array}{l}\text { Take leaves and roots of tree, stalk of endejai, boil together } \\
\text { into solution, } 1.5 \mathrm{~L} \text { on day } 1 \text { and } 1.5 \mathrm{~L} \text { on day } 3 \text {, rarely effective }\end{array}$ \\
\hline & Terminalia brownii & Orbukoi & $\begin{array}{l}\text { Chop up and boil, give } 1 \mathrm{~L} \text { of solution } 1 \times \text { day, every other day, } \\
\text { for } 3 \text { days, rarely effective }\end{array}$ \\
\hline & Sisala agave & Olkatani & $\begin{array}{l}\text { Chop up and boil leaf, give } 1 \mathrm{~L} \text { of solution every other day, for } \\
3 \text { days, rarely effective }\end{array}$ \\
\hline & Solanum incanum & Endulelei & $\begin{array}{l}\text { Take roots and ripe fruits of sodom apple, boil and mix with } \\
\text { tobacco powder, inject solution up nose, rarely effective }\end{array}$ \\
\hline & $\begin{array}{l}\text { Commiphora } \\
\text { zimmermanii }\end{array}$ & Arpande & $\begin{array}{l}\text { Boil bark and give solution to animal, } 350 \mathrm{~mL} 1 \times \text { day for } \\
4 \text { days, moderately effective }\end{array}$ \\
\hline & Cissus grandifolia & Endijai & $\begin{array}{l}\text { Boil stalk and feed to animal } 350 \mathrm{~mL} \text { of solution } 1 \times \text { daily until } \\
\text { recovered, very effective }\end{array}$ \\
\hline & Musa acuminata & Ormangulai & Feed solution to animal until condition improves, rarely effective \\
\hline & Terminalia brownii; & Orbukoi; & Boil or soak leaves overnight and give solution to animal, 1 \\
\hline & & & \\
\hline
\end{tabular}


Table-3: Continued...

\begin{tabular}{|c|c|c|c|}
\hline Disease & $\begin{array}{l}\text { Plant scientific } \\
\text { name }\end{array}$ & $\begin{array}{l}\text { Plant maa } \\
\text { name }\end{array}$ & Parts used, preparation, dosage, and effectiveness \\
\hline & Terminalia brownii & Orbukoi & $\begin{array}{l}\text { Boil bark and let cool, give solution to animal, } 1-2 \mathrm{~L}, 1-2 \times \text { day, } \\
\text { for } 3-10 \text { days, very effective }\end{array}$ \\
\hline & Salvadora persica & Oremit & $\begin{array}{l}\text { Scrape roots and grate into warm water, stir, and feed foam } \\
\text { solution produced to animal once, moderately effective }\end{array}$ \\
\hline & Terminalia brownii & Orbukoi & $\begin{array}{l}\text { Boil bark and wait for solution to cool; add soda ash, feed } \\
\text { animal } 700 \mathrm{~mL} \text { of solution } 1 \times \text { day for } 2 \text { days without water, } \\
\text { moderately effective }\end{array}$ \\
\hline \multirow[t]{4}{*}{$\begin{array}{l}\text { Sweating } \\
\text { sickness }\end{array}$} & Aloe vokensii & Engaramalasey & $\begin{array}{l}\text { Grind up roots and put in warm water; swirl until foamy and } \\
\text { bubbles form, bubble applied to tick areas once, very effective }\end{array}$ \\
\hline & Azadirachta indica & Engusero & $\begin{array}{l}\text { Take leaves and bark, give juice from them to animal, } 2 \times \text { day } \\
\text { for } 4 \text { days, very effective }\end{array}$ \\
\hline & Sisala agave & Olkatani & $\begin{array}{l}\text { Chop up and soak in water, give solution to animal, } \\
0.5 \mathrm{~L} 1 \times \text { day for } 3 \text { days, moderately effective }\end{array}$ \\
\hline & Aloe vokensii & Osukuroi & $\begin{array}{l}\text { Boil leaves into solution, give animal } 0.5 \mathrm{~L} 1 \times \text { day for } \\
2-3 \text { days, moderately effective }\end{array}$ \\
\hline \multirow[t]{5}{*}{ LSD } & Commiphora sp. & Oldemwai & $\begin{array}{l}\text { Apply juice from stems directly to backs } 1 \times \text { for } 5-7 \text { days (juice } \\
\text { can be bought), very effective }\end{array}$ \\
\hline & Aloe vokensii & Osukuroi & $\begin{array}{l}\text { Take fresh leaves, grind them up, mix with water, put } \\
\text { ointment on infection, once a day for } 4 \text { days, very effective }\end{array}$ \\
\hline & Ricinus communis & Ordulai & $\begin{array}{l}\text { Pound leaves and apply paste to wound site, once, very } \\
\text { effective }\end{array}$ \\
\hline & Opuntia vulgaris & Orpopongi & $\begin{array}{l}\text { Burn and crush up coals and press paste onto wounds, apply } \\
1 \times \text { daily for } 7 \text { days, moderately effective }\end{array}$ \\
\hline & Albizia gummifera & Ormokutan & $\begin{array}{l}\text { Burn and crush up coals and press paste onto wounds, apply } \\
1 \times \text { daily for } 7 \text { days, moderately effective }\end{array}$ \\
\hline \multirow[t]{7}{*}{ Red water } & $\begin{array}{l}\text { Commiphora } \\
\text { zimmermanii }\end{array}$ & Arpande & $\begin{array}{l}\text { Boil bark and give solution to animal, } 350 \mathrm{~mL} 1 \times \text { day for } \\
4 \text { days }\end{array}$ \\
\hline & Cissus grandifolia & Endijai & $\begin{array}{l}\text { Boil stalk and feed to animal } 350 \mathrm{~mL} 1 \times \text { daily until recovered, } \\
\text { very effective }\end{array}$ \\
\hline & Musa spp. & Olmaringu & Feed to animal until condition improves \\
\hline & $\begin{array}{l}\text { Terminalia brownii; } \\
\text { Aloe vokensii }\end{array}$ & $\begin{array}{l}\text { Orbukoi; } \\
\text { Osukuroi }\end{array}$ & $\begin{array}{l}\text { Boil or soak leaves overnight and give solution to animal, } \\
1 \mathrm{~L} 2 \times \text { day for } 5 \text { days }\end{array}$ \\
\hline & Terminalia brownii & Orbukoi & $\begin{array}{l}\text { Boil bark and let cool, give to animal, } 1-2 \mathrm{~L}, 1-2 \times \text { day, for } \\
3-10 \text { days }\end{array}$ \\
\hline & Salvadora persica & Oremit & $\begin{array}{l}\text { Scrape roots and grate into warm water, stir and feed foam } \\
\text { produce to animal once }\end{array}$ \\
\hline & Terminalia brownii & Orbukoi & $\begin{array}{l}\text { Boil bark and wait for solution to cool; add soda ash, feed } \\
\text { animal } 700 \mathrm{~mL} \text { of solution } 1 \times \text { day for } 2 \text { days without water }\end{array}$ \\
\hline
\end{tabular}

TBD=Tick-borne diseases, LSD=Lumpy skin disease, $E C F=$ East Coast Fever

Table-4: Non-plant materials used to treatment TBDs by Maasai people.

\begin{tabular}{|c|c|c|}
\hline Disease & Material used & Parts used, preparation, dosage, and mentioned efficacy \\
\hline dor disease & Sheep fat & Boil sheep fat, apply the ointment topically around mouth, moderately effective \\
\hline \multirow[t]{8}{*}{ LSD } & Salt and sugar & $\begin{array}{l}\text { Wash wounds with water, put salt and sugar paste on wound burn with hot } \\
\text { iron, very effective }\end{array}$ \\
\hline & Sheep fat & $\begin{array}{l}\text { Make a circle around lesion with hot iron, put sheep fat ointment on lesion, } \\
\text { burn lesion, once per spot, moderately effective }\end{array}$ \\
\hline & Sugar & Put sugar paste on affected skin and burn wound, moderately effective \\
\hline & Termite soil and ghee & $\begin{array}{l}\text { Wash wound, put termite soil and water paste onto wound, smear on ghee, } \\
\text { burn with iron, treat until healed, very effective }\end{array}$ \\
\hline & Fresh cattle dung & Spread cattle feces over spot, perform once per spot, moderately effective \\
\hline & Sheep fat & $\begin{array}{l}\text { Boil sheep fat to liquefy, inject into spot, perform once per spot, moderately } \\
\text { effective }\end{array}$ \\
\hline & Car engine oil & Rub oil on cows back, once a day until healed, moderately effective \\
\hline & Ghee & $\begin{array}{l}\text { Wash wound with water, mix soil with water, press on wound, smear ghee on } \\
\text { top, burn with hot iron, moderately effective }\end{array}$ \\
\hline
\end{tabular}

$\mathrm{TBD}=$ Tick borne diseases, $\mathrm{LSD}=$ Lumpy skin disease

oil was said to be applied on tick infected areas and the ticks would fall off. The traditional tick control methods the Maasai used are similar to those used by other ethnicities, e.g., the Bukusu of Western Kenya handpick ticks and burn them off, smoke cattle sheds to make ticks fall off, burn tick-infested pastures, and use ethnobotanical products to control ticks [26]. Indeed, hand picking of ticks, application of oil, and pasture burning are common tick control methods across Africa [27]. Considering that $50 \%$ of the respondents correctly related specific ticks with the specific disease they transmit indicates that knowledge 
of tick ecology is relatively good. In other studies, up to $57 \%$ of Maasai livestock keepers in Kenya associated ticks with ECF [5]. Consequently, it is likely that due to the Maasai people's reliance on livestock and their strong cultural attachment, they still have a fair knowledge of TBDs. However, only $7.5 \%$, of interviewed Maasai associated ticks with ECF [28]. The failure to link some of the diseases with tick vectors, e.g., red water [29] shows that traditional knowledge may be limited for disease diagnosis.

\section{Important medicinal plants for treatment of TBDs}

A total of 25 different plant species were used as ethnoveterinary medicine among Maasai. This is similar to other parts of Africa. For example, some farmers in South Africa use herbal remedies over conventional medicine to treat TBDs [30]. In the Kochore district of Gedeo Zone in Ethiopia, 40 plant species are used for ethnoveterinary purposes; 2 of these plants were used to treat TBDs [31]. In the Acholi Subregion of Uganda, 13 plant species belonging to 8 different families were said to control ticks in the area [32].

The Fabaceae family is widely used for ethnoveterinary medicine in Africa, e.g., among the Meru in Kenya, [33], Nhema in Zimbabwe, [34] and Venda of South Africa [35]. Overall, the development of traditional disease remedies has developed around plants that are readily and consistently available [33]. In our study, Aloe species were the most commonly mentioned plants utilized by the Maasai and were used for the treatment of six of the eight TBDs. Components of Aloe plants soothe external wounds and lesions such as those caused by LSD and can reduce internal inflammations [36]. LSD had the most treatment options mentioned, a result consistent with previous research that supports skin irritating ailments as being readily treatable [36].

The three most important plants for treatment of TBDs were Aloe volkensii, Cissus grandifolia, and Terminalia brownii. Plants of the genus Aloe have been used traditionally worldwide as a medicinal treatment for a wide variety of ailments due to their biologically active ingredients [37]. The compound aloin and its metabolic derivatives are effective against Trypanosoma congolese [38]. Hence, it may be worthwhile assessing its effectiveness against other protozoa-caused diseases, such as ECF and red water.

Plants of the Vitaceae family have also been investigated for anti-protozoal properties. Cissus multistriata was found to be effective against Trypanosoma brucei brucei [39]. The Combretaceae family has potentially active compounds such as polyphenols, flavonoids, tannins, saponins, and phytosterols, [39]. Terminalia brownii has been found to have antioxidant activities and to act as a hepatoprotective agent [40]. This is important as many TBDs can cause multi-system organ failure including liver damage [41]. Other Terminalia spp. and members of the Combretaceae family have been found to have anti-bacterial [42] and anti-trypanosomal compounds [43], suggesting that these plants could be of importance in modern pharmacology.

\section{Plant growth form, plant parts used, and plant availability}

The bark from different trees was used to treat seven of the eight TBDs. Trees (60\%) and shrubs $(22 \%)$ were the common growth forms used for making traditional remedies. However, other studies show that herbs are the more common medicinal plant form used in herbal remedies $[44,45]$. This could be because of the strong seasonality of rainfall in Northern Tanzania, which hinders the growth of many species of herbaceous plants during the dry season. Woody plant forms are easily accessible and readily available for use year round [46]. Plant leaves (30\%) were the most common part used. Leaves of 5 different plants were said to treat sweating sickness, heart water, ECF, LSD, corridor disease, anaplasmosis, and red water. Leaves of trees and succulent plants are readily available and easy to access. Use of leaves as the dominant part used is consistent with other research conducted throughout East Africa. Leaves often contain active chemicals and leaf harvesting does not inhibit the growth or survival of the plant species [45]. However, plant and plant part availability varies seasonally $[33,47]$

\section{Mode of remedy preparation, form of use, dosage, and effectiveness}

Most of the treatments were solutions prepared by boiling plant parts and then administering the solution to the animal orally. Other oral treatments commonly included mashing parts of plants, and administering the decoction to the animals. In general, the type of disease determines which application mode livestock keepers used for remedies. Topical applications were used for skin conditions and mashes and decoctions for internal ailments. The most common method of preparation was often boiling or soaking the plant in water. This allows time for the active ingredients to infuse into the water, thus detaching the chemicals and making the solution potent [48]. Furthermore, liquid solutions were easy to prepare without special equipment or advanced technology [36]. Mostly, 1-2 liters of oral solutions were reported to be administered to livestock; the frequency and duration of the treatments varied. While these are relatively large volumes, traditional treatments rarely have side effects [49]. Most traditional remedies are limited to trial and error [48] and thus variation in dosages can be due to season harvested, as chemical concentrations in plants vary by season [50]. Some of the plants have a strong bitter taste and are only administered in small dosages. Others are considered too "strong" and only given to livestock in small amounts. Livestock keepers also adjust dosages according to the size of the animal $[33,35]$. Other factors may be age and body condition, perceived "severity" of illness and the specific remedy availability. 
The reported effectiveness varied; however, the remedies were seen to be moderate to highly effective in treating TBDs. Most treatments for heartwater were seen to be ineffective while treatments for red water and anaplasmosis were often said to be effective. The efficacy of treatments for ECF and sweating sickness were said to depend on the stage of the disease. Often, traditional treatments are viewed as just as effective as modern medicine [51] and indeed laboratory experiments have confirmed the efficacy of certain plant families against bacteria and protozoans in vitro [42].

\section{Conclusion and Relevance}

The Maasai people interviewed could identify 6 tick species and knew about 8 TBDs. There were 25 species of plants identified and used in 59 treatments of TBDs among livestock. Many of the plant species and families used for TBD treatment (Aloe volkensii, Cissus grandifolia, Terminalia brownie; Families: Fabaceae, Euphorbiaceae, Solanaceae) are known to have pharmacological importance, further validating their credibility as ethnoveterinary medicine. This study emphasizes a need for an integrated approach in livestock health care in managing TBDs. The high use of traditional ethnoveterinary remedies highlights the need to support this as livestock health care practice. Rural based ethno-veterinary centers should be established and be able to investigate and confirm plants and treatments and standardize dosages, in order to maximize effectiveness.

\section{Authors' Contributions}

JK designed the study and helped in data collection, data analysis and manuscript preparation. JB and AS helped in data collection and in the initial manuscript preparation. CK provided useful scientific and technical input on the manuscript. All authors read and approved the final manuscript.

\section{Acknowledgments}

This study was financially and logistically supported by the School for Field Studies. It was conducted under TAWIRI permit no. 2014-323-ER2013-191 and approved by SFS scientific committee IRB-TZ-01-13. We thank the community members of Esilalei, Losirwa, and Eselela for whole heartedly sharing their knowledge with us.

\section{Competing Interests} interests.

The authors declare that there are no competing

\section{References}

1. Tarayia, G.N. (2004) The legal perspectives of the Maasai culture, customs, and traditions. Ariz. J. Int'l Comp. L., 21(1): $1-40$.

2. Wesonga, F.D., Kitala, P.M., Gathuma, J.M., Njenga, M.J. and Ngumi, P.N. (2010) An assessment of tick-borne diseases constraints to livestock production in a smallholder livestock production system in Machakos District, Kenya. Livest. Res. Rural Dev., 22(6): 1-8.
3. Martins, B., Di Giulio, S., Lynen, G., Peters G. and Rushton, J. (2010) Assessing the impact of East coast fever immunisation by the infection and treatment methods in Tanzanian pastoralist systems. Prev. Vet. Med., 97: 175-182.

4. Swai, E.S., Mbise, A.N., Kessy, V., Kaaya, E., Sanka, P. and Loomu, P.M. (2005) Farm constraints, cattle disease perception and tick management practices in pastoral Maasai community-Ngorongoro, Tanzania. Livest. Res. Rural Dev., 17(2): 1-11.

5. Jacob, O.M., Farah, K.O. and Ekaya, W.N. (2004) Indigenous knowledge: The basis of the Maasai ethnoveterinary diagnostic skills. J. Human. Ecol., 16(1): 43-48.

6. Schillhorn Van Veen, T.W. (1997) Sense or nonsense? Traditional methods of animal parasitic disease control. Vet. Parasitol., 71(2-3): 177-194.

7. Makundi, E., Malebo, H., Mhame, P., Kitua, A. and Warsame, M., (2006) Role of traditional healers in the management of severe malaria among children below 5 years of age: The case of Kilosa and Handeni Districts, Tanzania. Malar. J., 5: 58.

8. Masika, P.J. and Afolayan, A.J. (2003) An ethnobotanical study of plants used for treatment of livestock diseases in the Eastern cape province, South Africa. Pharm. Biol., 41(1): 16-21.

9. Prins, H.T. (1988) Plant phenology patterns in Lake Manyara National Park, Tanzania. J. Biogeogr., 15(1): 465-480.

10. Kiffner C., Wenner C., LaViolet A., Yeh K. and Kioko J. (2015) From savannah to farmland: effects of land use on mammal communities in the Tarangire-Manyara Ecosystem, Tanzania. Afr. J. Ecol., 53: 156-166.

11. Kabiri, N. (2011) Wildlife conservation and land acquisitions: A case study of the Tanzania Land Conservation Trust. International Conference on Global Land Grabbing, Land Deal Politics Initiative, 2012. file://C:/Users/sfspc7/ Downloads/Bertini-518-518_paper.pdf012. Accessed on 06-05-2015.

12. Goldman, M. and Riosmena, F. (2013) Adapting to variability and drought: The shifting relationship between institutions and landscapes in East Africa savanna lands. Glob. Environ. Chang., 23(3): 588-597.

13. Bee, F.K., Diyamett, M.L.N. and Towo, E.N. (2002) Challenges to traditional livelihoods and newly emerging employement patterns of pastoralists in Tanzania. International Labour Organization. International Labour Office, Geneva, Switzerland.

14. Tongco, D.C. (2007) Purposive sampling as a tool for informant selection. Ethnobot. Res. Appl., 5(1): 147-158.

15. Rabionet, S.E. (2011) How I learned to design and conduct semi-structured interviews: An ongoing and continuous journey. Qual. Rep., 16(2): 563-566.

16. McLeod, S.A. (2014) The Interview Method. Available from: http://www.simplypsychology.org/interviews.html. Accessed on 06-04-2015.

17. Kirby, C.S. (2007) Tick Management Handbook; An integrated guide for homeowners, pest control operators, and public health officials for the prevention of tick-associated disease.Connecticut Agricultural Experiment Station, New Haven. Bulletin 10.

18. Likert, R. (1932) A technique for the measurement of attitudes. Arch. Psychiatry, 22(104): 5-55.

19. Agnew, A.D.Q. and Agnew, S. (1994) Kenya Upland Wild Flowers. East African Natural History Society, Nairobi, Kenya.

20. Lubinga, J.C. (2014) The role of Rhipicephalus (Boophilus) decoloratus, Rhipicephalus appendiculatus and Amblyoma hebraeum ticks in the transmission of lumpy skin disease virus (LSDV). Biotechnology and Biological Sciences Research Council.

21. Cran, H. (2010) Tick borne diseases. Info-net Biovision. Available from: http://www.infonet-biovision.org/default/ ct/677/animalDiseases. Accessed on 06-04-2015. 
22. Madder, M., Horak, I., and Stoltsz, H. (2010) Ticks: Tick identification. University of Pretoria, Faculty of Veterinary Science, Pretorio, South Africa.

23. Bett, B., Jost, C., Allport, R. and Mariner, J. (2009) Using participatory epidemiological techniques to estimate the relative incidence and impact on livelihoods of livestock diseases amongst nomadic pastoralists in Turkana South District, Kenya. Prev. Vet. Med.,90: 194-203.

24. Moyo, B., Dube, S., Lesoli, M. and Masika, P. (2013) Seasonal habitat use and movement patterns of cattle grazing different rangeland types in the communal areas of the Eastern Cape, South Africa. J. Agric. Res., 8: 36-45.

25. Anderson, K., Ozenwa, V.O. and Jolles, A.E. (2013) Tick infestation patterns in free ranging African buffalo (Syncerus caffer): Effects of host innate immunity and niche segregation among tick species. Int. J. Parasitol. Parasites Widl., 2(1): 1-19.

26. Wanzala, W., Takken, W., Mukabana, W.R., Pala, A.O. and Hassanali, A. (2012) Ethnoknowledge of bukusu community on livestock tick prevention and control in Bungoma district, western Kenya. J. Ethnopharmacol., 140: 298-324.

27. Walker, A.R. (2011) Eradication and control of livestock ticks: Biological, economic and social perspectives. Parasitology., 138(8): 945-959.

28. Chenyambua, S.W., Waiswa, C., Saimo, M., Ngumi, M. and Gwakisa, P.S. (2010) Knowledge and perceptions of traditional livestock keepers on tick-borne diseases and sero-prevalence of Theileria parva around Lake Victoria Basin. Livest. Res. Rural Dev., 22(7): 1-12.

29. Nolan, J. (1987) Strategies to contain and eliminate outbreaks of acaricide resistance in the eradication of ticks. JOA Anim. Health Pro, 75: 186-195.

30. Masika, P.J., van Averbeke, W. and Sonandi, A. (2000) Use of herbal remedies by small-scale farmers to treat livestock diseases in central Eastern Cape Province, South Africa. $J$. S. Afr. Vet. Assoc., 71: 87-91.

31. Tekle, Y. (2014) An ethno-veterinary botanical survey of medicinal plants in Kochore district of Gedeo Zone, Southern Nations Nationalities and Peoples Regional State (SNNPRs), Ethiopia. J. Sci. Innov. Res., 3: 433-445.

32. Opiro, R., Akol, A.M. and Okello-Onen, J. (2010) Ethnoveterinary botanicals used for tick control in the Acholi Subregion of Uganda. J. Anim. Vet. Adv., 9: 2951-2954.

33. Gakuubi, M.M., Wanzala, W. (2012) A survey of plants and plant products traditionally used in livestock health management in Buuri district, Meru County, Kenya. J. Ethnobiol. Ethnomed., 8: 39.

34. Maroyi, A. (2012) Use of traditional veterinary medicine in Nhema Communal Area of the Midlands Province, Zimbabwe. Afr. J. Tradit. Complement Altern. Med., 9(3): 315-322.

35. Luseba, D. and Tshisikhawe, M.P. (2012) Medicinal plants used in the treatment of livestock diseases in Vhembe region, Limpopo province, South Africa. J. Med. Plants Res., 7(10): 593-601.

36. Van Der Merwe, D., Swan, G.E. and Botha, C.J. (2001) Use of ethnoveterinary medicinal plants in cattle by Setswanaspeaking people in the Madikwe area of the North West province of South Africa. J. S. Afr. Vet. Assoc., 72: 189-196.

37. Foster M, Hunter L, Samman S (2011). Evaluation of the nutritional and metabolic effects of Aloe Vera. In: Benzie IFF, Wachtel-Galor S. Herbal Medicine: Biomolecular and Clinical
Aspects. Second Ed, United States: CRC Press. pp. 37-54.

38. Tewabe, Y., Bisrat, D., Terefe, G. and Asres, K. (2014) Antitrypanosomal activity of aloin and its derivatives against Trypanosoma congolense field isolate. BMC Vet. Res. 10(61): 2-7.

39. James, O. and Emmanuel, J.J. (2011) Comparative evaluation of trypanocidal activities of Cissus multistriata and Saba florida (benth) leaf extracts. J. Biosci. Tech., 2(1): 197-204.

40. Fanta, B.S., Hiben, M.G., Gebremichael, L.G., Tefera, T.W., Periyasamy, G.K. and Kakoti, B.B. (2013) Hepatoprotective and antioxidant activity of Terminalia brownii leaf extract against carbon tetrachloride-induced liver injury in rats. Int. J. Pharm. Sci. Rev. Res., 23(1): 133-138.

41. Ismail, N., Bloch, K.C. and Mcbride, J.W. (2010) Human erlichiosis and anaplasmosis. Clin. Lab. Med., 30(1): 261-292.

42. Coulibaly, K., Zirihi, G.N., Guessennd-Kouadio, N., Oussou, K.R. and Dosso, M. (2014) Antibacterial properties studies of trunk barks of Terminalia ivorensis (Combretaceae), a commercial and medicinal species, on some methicillin-resistant Saphylococci spp strains. Afr. Health Sci., 14(3): 753-756.

43. Shuaibu, M.N., Ponchange, T.A.W., Yanagi, T., Hirayama, K., Ichinose, A., Tanaka, T. and Kouno, I. (2007) Trypanocidal activity of extracts and compounds from the stem bark of Anogeissus leiocarpus and Terminalia avicennoides. Parasitol. Res., 10(4): 697-703.

44. Mesfin, F., Demissew, S. and Teklehayamanot, T. (2009) An ethnobotanical study of medicinal plants in Wonago Woreda, SNNPR, Ethiopia. J. Ethnobiol. Ethnomed., 5(28): $1-18$.

45. Tolossa, K., Debela, E., Athanasiadou, S., Tolera, A., Ganga, G. and Houdijk, J.G.M. (2013) Ethno-medicinal study of plants used for treatment of human and livestock ailments by traditional healers in South Omo, Southern Ethiopia. Southern ethiopia. J. Ethnobiol. Ethnomed., 9: 32-47.

46. Getaneh, S. and Girma, Z. (2014) Ethnobotanical study of medicinal plants in Debre Libanos Wereda, Central ethiopia. Afr. J. Plant Sci., 8: 366-379.

47. Tomlinson, K.W., Poorter, L., Sterck, F.J., Borghetti, F., Ward, D., DeBie, S. and Van Langeveld, F. (2013) Leaf adaptations of evergreen and deciduous trees of semi-arid and humid savannas on three continents. J. Ecol., 101(2): 430-440.

48. Tamiru, F., Terfa, W., Kebede, E., Dabessa, G., Roy, R.K. and Sorsa, M. (2013) Ethnoknowledge of plants used in veterinary practices in Dabo Hana District, West Ethiopia. $J$. Med. Plant Res., 7: 2960-2971.

49. Acharya, R. and Acharya, K.P. (2009) Ethnobotanical study of medicinal plants used by Tharu community of Parroha VDC, Rupandehi District, Nepal. Sci. World, 7(7): 80-84.

50. Hess, S., Peres, M.T.L., Batista, A.L., Rodrigues, J.P., Tiviroli, S.C., Oliveira, L.G.L., Santos, C.W.C. and Fedel, E.S. (2007) Evaluation of seasonal changes in chemical composition and antibacterial activity of Elyonurus muticus (Sprengel) O. Kuntze (Gramineae). Quim Nova., 30(2): 370-373.

51. Dold, A.P. and Cocks, M.L. (2001) Traditional veterinary medicine in the Alice district of the Eastern Cape Province, South Africa. S. Afr. J. Sci., 97(9/10): 375-379. 